Таким образом, следует отметить, что в условиях реформирования законодательства об административных правонарушениях необходимо новое теоретическое осмысление проблем правоприменительной практики и правовой регламентации конкретных стадий производства по делам о мелком хулиганстве и определения приоритетных направлений совершенствования деятельности как должностных лиц, так и судей, участвующих в рассмотрении таких дел.

$$
* * *
$$

1. Кодекс Российской Федерации об административных правонарушениях Федеральный закон от 30 декабря 2001 г. № 195-Ф3 // Справочно-правовая система «КонсультантПлюс»: [Электронный pecypc] http://www.consultant.ru. (дата обращения 06.01.2021)

2. Кивич Ю.В. Проблемы, возникающие при рассмотрении судами дел о мелком хулиганстве // В сборнике: Конституционное и административное право: проблемы совершенствования публичной власти. Сборник научных трудов участников Международной научно-теоретической конференции. 2018. С. 98-104.

3. Светличная Т.Б., Слюсарева Т.Г. Проблемные вопросы административной ответственности за мелкое хулиганство // Пробелы в российском законодательстве. 2018. № 6. С. 297-300.

4. Постановление Кировского районного суда г. Кемерово по делу № 5-4/2017 от 05.01.2017 г. // [Электронный pecypc] https://sud-praktika.ru (Дата обращения 06.01.2021)

\title{
Портянко Е.М. \\ Портрет детоубийцы. Убийство матерью новорожденного ребёнка: криминологическая характеристика
}

Дальневосточный Федеральньй университет

(Россия, Владивосток)

doi: 10.18411/lj-04-2021-243

\section{Аннотация}

В статье анализируются статистические данные по количеству зарегистрированных убийств матерью новорожденного ребенка. Рассматривается криминологический портрет женщин-детоубийц. Особое внимание уделяется их социально-демографическим характеристикам. Выделяются внешние обстоятельства, выступающие в роли причин, которые толкают женщин на убийство своего новорожденного ребенка.

Ключевые слова: мать-убийца, новорожденный, статистические данные, криминологическая характеристика, социально-демографические признаки, причины убийства новорожденного.

\section{Abstract}

The article analyzes statistical data on the number of recorded murders by the mother of a newborn child. A criminological portrait of female child murderers is considered. Special attention is paid to their socio-demographic characteristics. External circumstances stand out that play the role of reasons that push women to kill their newborn baby.

Keywords: mother-killer, newborn, statistical data, criminological characteristics, socio-demographic signs, causes of killing a newborn.

Актуальность вопроса борьбы с убийствами матерью новорожденного ребенка подтверждает статистика распространения детоубийства в РФ. Так, согласно официальной статистике Генеральной прокуратуры Российской Федерации за 2010 2020 гг. было зарегистрировано 1162 преступлений, квалифицированных по статье 106 УК РФ (рис.1).

Несмотря на явную тенденцию к снижению ситуация остается неблагоприятной. 


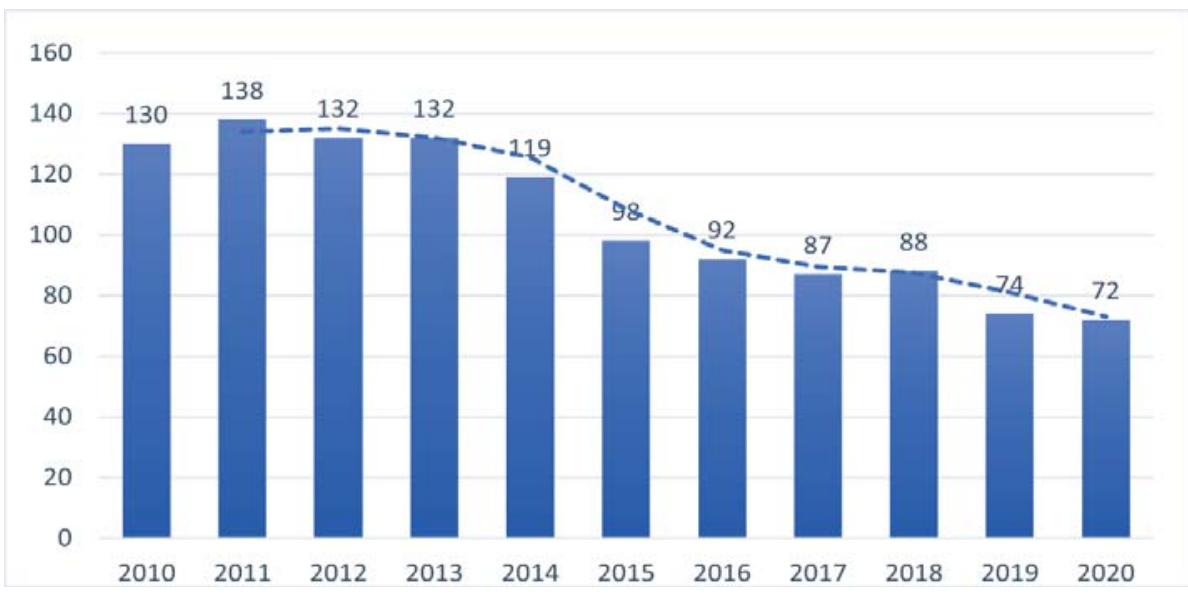

Рис. 1. Количество зарегистрированных преступлений по ст. 106 УК РФ за 2010-2019 2.

Автором настоящей статьи предпринята попытка дать криминологическую характеристику личности матери, совершившей убийство новорожденного ребенка, выявить причины, спровоцировавшие виновную на это преступление.

Для этих целей автором были изучены и проанализированы 100 приговоров судов по ст. 106 УК РФ, опубликованные на интернет - ресурсе «Судебные и нормативные акты РФ», за последние 5 лет (2014 - 2020 гг.).

Криминологическая характеристика. Ключевым элементом криминологической характеристики личности преступника являются его социальнодемографические признаки. Так, к социально-демографическим признакам личности преступника относятся: возраст, гражданство, место проживания, образование, наличие постоянной работы, семейное положение, наличие детей, наличие судимости.

Возраст. Анализ приговоров судов показал, что средний возраст субъекта преступления находится в пределах 30 лет и старше. Жизненная активность женщин в 30 - 49 лет в целом наиболее высока. Их криминальное поведение объясняется, с одной стороны, возможностями, полученными женщиной в условиях профессиональной и иной активной деятельности, с другой - неспособностью противостоять неудачам в разных сферах жизнедеятельности.

Согласно результатам анализа матерей-школьниц 16 лет, убивших своих новорожденных детей, оказалось около 5 \%, девушек в возрасте от 16 до 18 лет - около $7 \%$. Причиной такого поведения чаще всего являются разного рода психологические травмы, а именно: стресс от неожиданной беременности в раннем возрасте, боязнь общественного порицания.

Матерей, совершивших убийство своих новорожденных детей в возрасте $18-25$ лет, около $12 \%$. Причинами принятия такого решения являются стыд за рождение ребенка вне брака, боязнь лишиться работы и (или) учебы; невозможность обеспечить ребенка всем необходимым.

В возрастной группе 25 - 30 лет убийство новорожденного ребенка совершается почти в 20 \% зафиксированных случаев. Наиболее типичными причинами являются: значительные финансовые затруднения и неблагоприятные жилищные условия, рождение ребенка вне брака, мнение женщины, что ребенок будет препятствовать ее личному счастью и т. п.

Практически 50 \% детоубийств совершается женщинами в возрасте от 30 до 40 лет как в самой репродуктивно активной возрастной группе.

Причинами совершения детоубийства женщинами старше 40 лет (6 \%) являются: боязнь различных генетических заболеваний, отсутствие надлежащего здоровья и жизненных сил для вынашивания, рождения и воспитания ребенка, недостаточное материальное стимулирование семей и матерей-одиночек, плохие жилищные условия и другие. 
Гражданство. Во всех анализированных нами приговорах все женщиныпреступницы имели гражданство Российской Федерации.

Место проживания. Анализ проводился по приговорам судов всех субъектов РФ. Так, результаты исследования говорят, что 68\% женщин, совершивших убийство новорожденного ребенка, проживали в городской местности (города, поселки), соответственно, $32 \%$ проживали в сельской местности.

Образование. Социальную сторону жизни и деятельности человека во многом определяет его образовательный уровень. В приговорах, в которых была указана данная информация, большинство женщин имели среднее профессиональное образование - $49 \%$, среднее общее - почти $28 \%$, основное общее образование - $16 \%$. Женщин-детоубийц, получивших высшее профессиональное образование около 7 \%.

Наличие постоянной работы. Анализ приговоров судов, в которых содержались данные о наличии работы у преступниц показал, что женщины с постоянным местом работы совершали убийство новорожденных детей примерно в 12 $\%$ случаев, временно работающие - $25 \%$, временно безработные и работающие периодами - в 48 \% случаев. Примерно в $15 \%$ случаев женщины имели разного рода «подработки».

Семейное положение. Анализ приговоров показал, что только $18 \%$ подсудимых состояли в браке, 32 \% - были разведены, 35 \% - жили с сожителем, 15\% были незамужними.

Это не говорит о том, что основное большинство женщин негативно относятся к такому социальному институту как семья. Многие из них забеременев, надеются выйти замуж за отца своего ребенка, но он оставляет женщину самостоятельно рожать и воспитывать ребенка, либо своим активным поведением на протяжении всей беременности внушает ей мысль о ненужности ребенка.

Наличие детей. На момент совершения преступления почти $22 \%$ женщин воспитывали двух и более детей, примерно у $45 \%$ имелся один ребенок, а у 33 \% убитый новорожденный был первенцем. Таким, образом, наличие у женщины кровных детей не является гарантом того, что новорожденный ребенок не может быть убит.

Наличие судимости. В анализируемых приговорах только в 9 \% случаях фигурировала подсудимая с наличием судимости, все остальные ранее не судимы (91\%). Причем 5\% были судимы за преступления против жизни и здоровья.

Систематизировав совокупность данных, полученных в ходе проведенного нами исследования, можно составить сводный криминологический портрет матери, совершившей убийство своего новорожденного ребенка.

Это гражданка РФ (100\%), в возрасте от 30 до 40 лет (50\%), проживающая в городской местности (68 \%), имеющая среднее общее или среднее профессиональное образование (77\%), безработная или работающая периодами (48 \%), не состоящая в зарегистрированном браке (82 \%), выросшая в неполной семье $(64 \%)$ и в неблагоприятных жизненных условиях (86 \%), имеющая одного и более ребенка (67 $\%)$, ранее не судимая (91 \%), злоупотребляющая алкоголем (29\%) или наркозависимая (7\%), не состоящая на учете в специализированных учреждениях (84 \%) и имеющая послеродовые расстройства психики (около 50 \%).

Основными причинами убийства матерью новорожденного ребенка являются: ложное чувство стыда, боязнь общественного осуждения, отсутствие поддержки родных, семейные проблемы, неблагоприятные жилищные условия и неустроенность быта, страх перед материальными трудностями, боязнь потерять возможность реализоваться в профессиональном и личном плане, различные расстройства психики.

$$
* * *
$$

1. Антонян, Ю.М., Гончарова, М. В., Кургузкина Е.Б. Убийство матерью новорожденного ребенка: уголовно-правовые и криминологические проблемы / Ю.М. Антонян, М. В. Гончарова, Е.Б. Кургузкина // Lex russica. 2018. № 3 (136). C. 94-114. 
2. Вакалюк, Е.С. Криминологическая характеристика матери-убийцы / Е.С. Вакалюк // Научное обозрение. Серия 2: Гуманитарные науки. 2012. № 5. С. 197-201.

3. Натура, А.И., Злобина, Л. А. Социально-психологический статус матери-убийцы новорожденного ребенка как элемент криминалистической характеристики преступления / А.И. Натура, Л. А. Злобина // Теория и практика общественного развития. 2017. № 12. С. 134-138.

4. Резник, Ж.Я. Социально-психологический и демографический статус матери - убийцы новорожденного ребенка как элементы криминологической характеристики личности / Ж. Я. Резник // Вестник Самарского юридического института. 2018. №5. С.131-135.

5. Середа, Е.В. Применение наказания в виде лишения свободы в отношении женщин: учебное пособие / Е.В. Середа. Рязань: Изд-во Рязан. ин-та права и экономики и права, 2000. 50 с.

6. Портал правовой статистики Генеральной прокуратуры Российской Федерации [Электронный pecypc]. Режим доступа: https: // crimestat.ru/ Загл. с экрана.

\section{Пузиков С.А. \\ Особенности правового регулирования отношений, возникающих в сфере технического обслуживания внутридомового газового оборудования (ТО ВДГО)}

Волгоградский государственньй университет (Россия, Волгоград)

doi: 10.18411/lj-04-2021-244

\section{Аннотация}

В статье кратко рассмотрены отдельные проблемные вопросы, связанные с недостатками законодательного регулирования деятельности по техническому обслуживанию внутридомового газового оборудования

Ключевые слова: внутридомовое газовое оборудование, газоснабжение, специализированные организации.

Keywords: indoor gas equipment, gas supply, specialized organizations.

Техническое и аварийно-диспетчерское обслуживание внутридомового газового оборудования, являясь необходимым элементом процесса газоснабжения, фактически производились с момента начала массовой газификации в СССР, начиная со второй половины XX века. Тем не менее, первое упоминание о договоре о техническом обслуживании внутридомового газового оборудования и аварийно-диспетчерском обеспечении (далее договор о ТО ВДГО) в нормативном акте, принятом на уровне Правительства РФ, содержится в Правилах поставки газа для коммунально-бытовых нужд граждан (Правил), утвержденных Постановлением Правительства РФ № 549 от 21.07.2008г. Возможно, что принятие Правил было продиктовано необходимостью изменения негативных тенденций, сложившихся в сфере газоснабжения населения в связи с проводимыми в двухтысячные годы реформами, в результате которых реализация газа населению была отделена от эксплуатации и технического обслуживания внутридомового газового оборудования, а обязанность по его поддержанию в надлежащем техническом состоянии возложена на собственников оборудования - физических лиц. В результате неисполнения собственниками указанных обязанностей, в целом по Российской Федерации и в Волгоградской области, в частности, продолжает фиксироваться значительное количество инцидентов и аварийных ситуаций, связанных с использованием газового оборудования в быту, в том числе с человеческими жертвами. Информация об этом закрытой не является и регулярно появляется на страницах федеральных и региональных СМИ. Ситуация оказалась настолько острой, что Правительство РФ постановлением от 14.05.2013 N 410 утвердило Правила пользования газом в части обеспечения безопасности при использовании и содержании внутридомового и внутриквартирного газового 